\title{
Aboveground and Belowground Carbon Pools After Fire in Mountain Big Sagebrush Steppe
}

\author{
Meagan B. Cleary, ${ }^{1}$ Elise Pendall, ${ }^{2,3}$ and Brent E. Ewers ${ }^{2,3}$ \\ Authors are ${ }^{1}$ Adjunct Faculty, Moraine Valley Community College, Palos Hills, IL 60465, USA; and Associate Professors, ${ }^{2}$ Department of Botany and \\ ${ }^{3}$ Program in Ecology, University of Wyoming, 1000 E University Ave, Laramie, WY 82071, USA.
}

\begin{abstract}
Postfire succession in mountain big sagebrush (Artemisia tridentata Nutt. subsp. vaseyana [Rydb.] Beetle) ecosystems results in a gradual shift from herbaceous dominance to dominance by shrubs. Determining the quality, quantity, and distribution of carbon (C) in rangelands at all stages of succession provides critical baseline data for improving predictions about how $\mathrm{C}$ cycling will change at all stages of succession under altered climate conditions. This study quantified the mass and distribution of above- and belowground (to 1.8 -m depth) biomass at four successional stages $(2,6,20$, and $39 \mathrm{yr}$ since fire) in Wyoming to estimate rates of $\mathrm{C}$ pool accumulation and to quantify changes in ecosystem carbon to nitrogen $(\mathrm{C}: \mathrm{N})$ ratios of the pools during recovery after fire. We hypothesized that biomass $\mathrm{C}$ pools would increase over time after fire and that $\mathrm{C}: \mathrm{N}$ ratios would vary more between pools than during succession. Aboveground and live coarse roots (CR) biomass increased to 310 and $17 \mathrm{~g} \mathrm{C} \cdot \mathrm{m}^{-2}$, but live fine roots (FR) mass was static at about $225 \mathrm{~g} \mathrm{C} \cdot \mathrm{m}^{-2}$. Fine litter $(\leq 1-\mathrm{cm}$ diameter) accounted for about $70 \%$ of ecosystem $\mathrm{C}$ accumulation rate, suggesting that sagebrush leaves decompose slowly and contribute to a substantial soil organic carbon (SOC) pool that did not change during the $40 \mathrm{yr}$ studied. Total ecosystem C (not including SOC) increased $16 \mathrm{~g} \cdot \mathrm{m}^{-2} \cdot \mathrm{yr}^{-1}$ over $39 \mathrm{yr}$ to a maximum of $1100 \mathrm{~g} \cdot \mathrm{m}^{-2}$; the fastest accumulation occurred during the first $20 \mathrm{yr}$. C:N ratios ranged from 11 for forb leaves to 110 for large sagebrush wood and from 85 for live CR to 12 for bulk soil and were constant across growth stages. These systems may be resilient to grazing after fire because of vigorous regrowth of persistent bunchgrasses and stable pools of live FR and SOC.
\end{abstract}

\section{Resumen}

La sucesión post-fuego en ecosistemas de Artemisia tridentata Nutt. spp. vaseyana (Rydb.) Beetle resulta en una conversión gradual de dominancia herbácea a dominancia de arbustos. La determinación de la calidad, cantidad y distribución de C en pastizales en todos los estadios de sucesión provee datos críticos de punto de referencia del sistema para mejorar las predicciones sobre cómo cambiara el ciclado de $\mathrm{C}$ en cada estadio de sucesión bajo condiciones climáticas alteradas. Este estudio cuantificó la masa y distribución de de biomasa aérea y subterránea (hasta $1.8 \mathrm{~m}$ de profundidad) en cuatro etapas de sucesión (2, 6, 20, y 39 años desde el fuego) en Wyoming, EE.UU., para estimar las tasas de acumulación de reservorios de C, y cuantificar cambios en la relación C:N del ecosistema en los reservorios durante la recuperación posterior al fuego. Postulamos que los reservorios de C en la biomasa aumentarían a través del tiempo luego del fuego y que la relación C:N variaría mas ente reservorios que durante las etapas de sucesión. La biomasa aérea y de raíces gruesas $(\mathrm{RG})$ aumentó a 310 y $17 \mathrm{~g} \mathrm{C} \cdot \mathrm{m}^{-2}$, pero la masa de raíces finas vivas $(\mathrm{RF})$ se mantuvo estática en aproximadamente $225 \mathrm{~g} \mathrm{C} \cdot \mathrm{m}^{-2}$. La broza fina (diámetro $\leq 1 \mathrm{~cm}$ ) representó el $70 \%$ de la tasa de acumulación de C del ecosistema, sugiriendo que las hojas de la Artemisia se descomponen lentamente y contribuyen a un reservorio de COS (carbono orgánico del suelo) sustancial que no cambió a lo largo de los 40 años estudiados. El C total del ecosistema (sin incluir el COS) aumentó $16 \mathrm{~g} \cdot \mathrm{m}^{-2} \cdot$ año $^{-1}$ en el período de 39 años a un máximo de $1100 \mathrm{~g} \cdot \mathrm{m}^{-2}$; la acumulación más rápida ocurrió en los primeros 20 años. La relación C:N osciló entre 11 para hojas de hierbas y 110 en madera de arbustos grandes de Artemisia, y entre 85 para RG vivas y 12 para el suelo y permanecieron constantes a través de los periodos de crecimiento. Estos sistemas pastoreados podrían tener buena capacidad de recuperación luego del fuego debido al rebrote vigoroso de pastos persistentes y reservorios estables de RF y COS.

Key Words: Artemisia tridentata, C:N ratio, litter layer, root biomass, root distribution, soil organic matter

Research was funded by the National Research Initiative of the USDA Cooperative State Research, Education and Extension Service Grant 2003-35101-13652, a Graduate Student Fellowship from the Wyoming Space Grant Consortium, and the Wyoming Agricultural Experiment Station.

Mention of a proprietary product does not constitute a guarantee or warranty of the product by the University of Wyoming, the USDA, or the authors and does not imply its approval to the exclusion of the other products that also may be suitable.

At the time of the research, the first author was a PhD graduate student, Dept of Botany, University of Wyoming, Laramie, WY 82071, USA.

Correspondence: Meagan Cleary, Blue Island Education Center-MVCC, 12940 S Western Ave, Blue Island, IL 60406, USA. Email: meagan.cleary@yahoo.com

Manuscript received 18 August 2009; manuscript accepted 7 December 2009.

\section{INTRODUCTION}

Semiarid shrublands dominated by big sagebrush (Artemisia tridentata Nutt.) encompass as much as $11 \%$ of North America (West 1983; Frisina and Wambolt 2004) and are important in continental-scale carbon (C) storage (Jackson et al. 2002). In these areas there is substantial biomass $\mathrm{C}$ accumulation potential as vegetation shifts from perennial grasses and forbs to shrubs and cover increases linearly for decades following burning (Cleary et al. 2008; Ewers and Pendall 2008). Carbon sequestration from the atmosphere increases during succession 
as woody biomass accumulates aboveground (Knapp et al. 2008) and as woody roots and soil organic matter (SOM) accumulate belowground (Lorenz and Lal 2005). Carbon cycling in rangelands is understudied in relation to their extent and susceptibility to climate change and may be impacted by recent changes in disturbance including grazing and fire frequency (Bates et al. 2009).

Determining the quality, quantity, and distribution of $\mathrm{C}$ in rangelands at all stages of succession provides critical baseline data for improving predictions about how $\mathrm{C}$ cycling will change at all stages of succession under altered climate conditions (Subke et al. 2006). However, evaluating C accumulation during succession often relies on chronosequence assumptions, which are undergoing increased scrutiny (Johnson and Miyanishi 2008; Myster and Malahy 2008). Despite the scrutiny, aboveground succession patterns of Wyoming big sagebrush (Artemisia tridentata Nutt. subsp. vaseyana [Rydb.] Beetle) are well documented (Harniss and Murray 1973; Wambolt et al. 2001; Bates et al. 2009) and have been found across replicated chronosequences in Wyoming (Cleary et al. 2008; Ewers and Pendall 2008). In addition to aboveground biomass, careful measurements of well-defined belowground C pools are required to reduce uncertainties associated with successional effects on C cycling (Bradley et al. 2006).

Aboveground biomass comprises about $50 \%$ of total biomass in shrub ecosystems (Chapin et al. 2002). When deposited on the soil, aboveground biomass gives rise to a patchy litter layer, important for water retention, nutrient cycling, and C storage (Boeken and Orenstein 2001). Litter from aboveground biomass incorporated into soil is generally limited to the top $0.30 \mathrm{~m}$ (Chen and Stark 2000) and may be of different quantity and quality than belowground litter from dead roots (Lorenz and Lal 2005).

Belowground biomass includes fine roots $(\mathrm{FR}, \leq 2-\mathrm{mm}$ diameter) and coarse roots (CR, $>2$-mm diameter). Live FR production, turnover, and exudation comprise the principal contributions to soil C (Norby and Jackson 2000). During succession in oak forests, FR biomass is $<50 \%$ of the mature stage for several years after disturbance and increases to almost double the mature mass until canopy closure, when it slowly decreases back to steady state (Yin et al. 1989). This pattern of belowground biomass succession has mixed support in forest ecosystems (Gough et al. 2007) and has not been quantified in shrublands. Live CR in shrublands spread horizontally in upper layers to provide plant stability and soil exploitation and extend vertically into the soil to access water during drought (Sturges 1977; Donovan and Ehleringer 1994) and to take up nutrients (McCulley et al. 2004). During recovery from fire in forests, CR increase with increasing woody biomass aboveground (Gough et al. 2007); shrublands may or may not have a similar response. Because CR may be deeper and have higher carbon to nitrogen ratios (C:N) than FR, CR may be important for determining deep $(\geq 1 \mathrm{~m})$ soil C storage (Jobbágy and Jackson 2000; Lorenz and Lal 2005).

Contributions of aboveground litter and dead roots drive a decay continuum in the soil that describes the transformation of intact litter with high C:N to fragmented, decomposed material with relatively low C:N (Melillo et al. 1989). The C:N ratios decrease because of C-limited soil microbes that respire $\mathrm{CO}_{2}$ and immobilize $\mathrm{N}$ in recalcitrant humic substances during decomposition (Chapin et al. 2002). Values of C:N for different pools are used to estimate organic matter turnover rates in biogeochemical models (Paustian et al. 1992; Thornley and Cannell 1997). Changes in $\mathrm{C}: \mathrm{N}$ of ecosystem biomass pools may contribute to altered decomposition dynamics during succession (Yanai et al. 2003).

To address the potential importance of each $\mathrm{C}$ pool for continental-wide $\mathrm{C}$ accumulation and $\mathrm{C}$ cycling after fire in rangelands, this study quantifies the mass and distribution of $\mathrm{C}$ and $\mathrm{C}: \mathrm{N}$ ratios in above- and belowground pools at different succession stages following fire in sagebrush steppe. We hypothesize that during aboveground plant succession after fire, 1) the mass and vertical structure of live root biomass correlate to aboveground biomass, 2) aboveground litter increases continuously while belowground litter (i.e., dead roots) peaks immediately after the fire, 3 ) soil organic $\mathrm{C}$ in mineral horizons does not change, and 4) C:N differs more among $\mathrm{C}$ pools than succession stages.

\section{METHODS}

\section{Site Description}

A mountain big sagebrush (Artemisia tridentata Nutt. subsp. vaseyana [Rydb.] Beetle) fire recovery sequence was selected in south-central Wyoming (Cleary et al. 2008). The chronosequence approach provides valuable insights into plant succession and can potentially inform $\mathrm{C}$ sequestration policy decisions (Foster and Tilman 2000; Law et al. 2003; Yanai et al. 2003). However, it can lead to erroneous interpretations if climate, soils, or other factors, such as seed availability, vary substantially across sites (Johnson and Miyanishi 2008). Aboveground biomass changes during succession have been tested across three replicated chronosequences in Wyoming (Ewers and Pendall 2008), which increases the support of using the chronosequence approach to assess decadal dynamics of $\mathrm{C}$ pools in sagebrush steppe.

The site in this study contained four growth stages defined by the number of years since fire (ysf) in 2005, which were termed "recent burn" (2 ysf), "establishment" (6 ysf), "expansion" (20 ysf), and "mature" (39 ysf). The stages were within $3 \mathrm{~km}$ of each other and had similar topographic characteristics (elevation 2280-2310 m and $<1 \%$ slope; Table 1). All four stages had thick $(\geq 0.40-\mathrm{m})$ mollic epipedons and loam textures. Herbaceous cover was dominated by graminoids and forbs, including wheatgrass (Pascopyrum smithii [Rydb.] A. Löve), needle and thread (Hesperostipa comata [Trin. \& Rupr.] Barkworth), and silvery lupine (Lupinus argenteus Pursh). Mean annual temperature at Saratoga, Wyoming $(50 \mathrm{~km}$ from the site), was $6.8^{\circ} \mathrm{C}$, and mean annual precipitation was $248 \mathrm{~mm}$, nearly $50 \%$ of which occurred in April-July (Ewers and Pendall 2008). Total precipitation in Saratoga from 1 October 2004 to 30 September 2005 was $229 \mathrm{~mm}$, of which $137 \mathrm{~mm}$ occurred between April and September (Western Regional Climate Center 2007). All sampling was completed near peak growth in the summer of 2005, and sampling plots were located at least $1.5 \mathrm{~m}$ apart, which is adequate distance to be spatially independent (Ewers and Pendall 2008). 
Table 1. Ecosystem properties (SE) for four sagebrush growth stages during recovery after fire defined by the number of years since fire (ysf). Letters indicate significant differences $(P<0.05)$ between stages, and $L A I=$ leaf area index. Depths above which $50 \%$ of mass was found $\left(D_{50}\right)$ and $\beta$ values are inset in Figures 2 and 3.

\begin{tabular}{|c|c|c|c|c|c|}
\hline & \multirow[b]{2}{*}{$n$} & \multicolumn{4}{|c|}{ Growth stages } \\
\hline & & Recent burn & Establishment & Expansion & Mature \\
\hline Age (ysf) & & 2 & 6 & 20 & 39 \\
\hline Elevation (m) & & 2309 & 2260 & 2283 & 2250 \\
\hline Lat & & $41^{\circ} 18^{\prime} 13^{\prime \prime} \mathrm{N}$ & $41^{\circ} 19^{\prime} 52^{\prime \prime} \mathrm{N}$ & $41^{\circ} 21^{\prime} 48.9^{\prime \prime} \mathrm{N}$ & $41^{\circ} 19^{\prime} 53^{\prime \prime} \mathrm{N}$ \\
\hline Long & & $107^{\circ} 19^{\prime} 33^{\prime \prime} W$ & $107^{\circ} 24^{\prime} 2.4^{\prime \prime} \mathrm{W}$ & $107^{\circ} 21^{\prime} 18^{\prime \prime} \mathrm{W}$ & $107^{\circ} 24^{\prime} 3.9^{\prime \prime} \mathrm{W}$ \\
\hline \multicolumn{6}{|l|}{ Aboveground biomass indices } \\
\hline $\operatorname{LAI}\left(\mathrm{m}^{2} \cdot \mathrm{m}^{-2}\right)$ & 40 & $0.25(0.05) \mathrm{a}$ & $0.51(0.09) \mathrm{a}$ & $0.85(0.14) b$ & $1.2(0.11) \mathrm{c}$ \\
\hline Shrub cover $(\%)^{1}$ & 4 & $0.03(0.03) \mathrm{a}$ & $0.45(0.45) \mathrm{a}$ & $12(3.1) b$ & $19(7.1) b$ \\
\hline Total cover $(\%)$ & 4 & $22(5.7) \mathrm{a}$ & $27(1.1) \mathrm{a}$ & $46(4.9) b$ & $64(4.2) \mathrm{c}$ \\
\hline \multicolumn{6}{|l|}{ Soil A horizon properties ${ }^{2}$} \\
\hline Texture in top $0.40 \mathrm{~m}$ & & Sandy loam & Sandy clay loam & Sandy loam & Clay loam \\
\hline$\%$ Sand & 3 & $62(4.2) \mathrm{c}$ & $46(6.8) b$ & $68(3.8) d$ & $39(7.8)$ a \\
\hline$\%$ Silt & 3 & $22(4.3) b$ & $27(3.0) \mathrm{c}$ & $16(2.2) \mathrm{a}$ & $29(3.6) c$ \\
\hline$\%$ Clay & 3 & $17(1.9) \mathrm{a}$ & $27(7.0) \mathrm{b}$ & $16(2.2) \mathrm{a}$ & $31(11) b$ \\
\hline $\mathrm{pH}$ in top $0.40 \mathrm{~m}$ & 12 & $6.2(0.07) \mathrm{a}$ & $7.6(0.19) \mathrm{c}$ & $7.0(0.09) b$ & $6.3(0.07) \mathrm{a}$ \\
\hline \multicolumn{6}{|l|}{ Munsell color } \\
\hline Dry & 3 & 10YR 4/2 & 10YR $4 / 3$ & 10YR $3 / 2$ & 10YR $4 / 2$ \\
\hline Wet & 3 & 7.5YR $2.5 / 1$ & 10YR 2/2 & 7.5YR 2.5/1 & 10YR 2/2 \\
\hline Total live fine roots in top $0.25 \mathrm{~m}(\%)^{3}$ & 3 & $73(2.1) \mathrm{a}$ & $74(2.7) \mathrm{a}$ & $68(3.6)$ a & $67(3.7) \mathrm{a}$ \\
\hline
\end{tabular}

${ }^{1}$ Includes nonsagebrush and sagebrush shrubs and was $\log _{10}$ transformed to compute significant differences.

${ }^{2}$ Soil from all depths and profiles was analyzed for wet and dry Munsell color, pH in a 2:1 paste, bulk density, and particle size using the hydrometer method (GLOBE 2005). Bulk density was $0.83 \pm 0.03 \mathrm{~g} \cdot \mathrm{cm}^{-3}$ in the top $0.10 \mathrm{~m}$ and $1.2 \pm 0.03 \mathrm{~g} \cdot \mathrm{cm}^{-3}$ between $0.10-\mathrm{m}$ and $0.40-\mathrm{m}$ depth for all stages $(P<0.001)$.

${ }^{3}$ Mean for all years since fire was $70(2.8)$.

\section{Aboveground Carbon Pools and Indices}

Biomass and Indices. Sagebrush biomass was calculated from allometric relationships using shrub density and canopy volumes from six $4-\mathrm{m}^{2}$ plots at each stage (Cleary et al. 2008). Graminoid, forb, and nonsagebrush shrub biomasses were quantified from 16 random samples at each growth stage by clipping all vegetation (except big sagebrush) within $0.1-\mathrm{m}^{2}$ plots, drying it at $60^{\circ} \mathrm{C}$ for $48 \mathrm{~h}$, sorting it into functional groups, and weighing each group. Subsamples of $P$. smithii and $L$. argenteus leaves and $A$. tridentata leaves, inflorescences, new stem growth, wood $\leq 1-\mathrm{cm}$ diameter, and wood $>1-\mathrm{cm}$ diameter were ground in a ball mill and combusted in an elemental analyzer to determine $\mathrm{C}, \mathrm{N}$, and C:N (Elementar 2004). Percent cover of graminoid basal area, forbs, and shrubs (Perry et al. 2002) and leaf area index (LAI) were measured using the line intercept method along four parallel $10-\mathrm{m}$ transects at least $4 \mathrm{~m}$ apart at each growth stage (Ewers and Pendall 2008).

Litter. The litter layer was collected from three $0.5 \times 0.5 \mathrm{~m}$ plots at each growth stage and was separated into size classes of $\leq 1-\mathrm{cm}$ and $>1-\mathrm{cm}$ diameters. Based on observation of the two size classes, litter $\leq 1 \mathrm{~cm}$ was a mixture of leaves, new growth, and small twigs; litter $>1-\mathrm{cm}$ diameter was exclusively $A$. tridentata wood. Therefore, we determined $\mathrm{C}$ and $\mathrm{N}$ content of the litter layer assuming that litter $\leq 1-\mathrm{cm}$ diameter was equal to the nonweighted mean of $\mathrm{C}$ and $\mathrm{N}$ content of a mixture of all aboveground components except $A$. tridentata wood $>1-\mathrm{cm}$ diameter and that $\mathrm{C}$ and $\mathrm{N}$ content of litter $>1-\mathrm{cm}$ diameter was equal to the content of $A$. tridentata wood $>1-\mathrm{cm}$ diameter.

\section{Belowground Carbon Pools}

Soil and root samples were collected from three profiles using the trench method (Silva and Rego 2003). Samples of known volume were collected by coring from profile faces at nine depths $(0-0.10,0.10-0.15,0.15-0.25,0.25-0.40,0.40-0.60$, $0.60-0.90,0.90-1.20,1.20-1.50$, and $1.50-1.80 \mathrm{~m}$ ) except at the mature stage, which was sampled to $1.2-\mathrm{m}$ depth.

Biomass and Litter. Live and dead FR ( $\leq 2-\mathrm{mm}$ diameter), dead CR (>2-mm diameter), and litter from aboveground biomass incorporated into mineral soil (LIS) were quantified from polyvinyl chloride (PVC) cores of known volume and weight. Live CR $\left(\mathrm{kg} \cdot \mathrm{m}^{-2}\right)$ were estimated using allometric relationships but were underestimated because the allometric relationships included only roots to $0.25-\mathrm{m}$ depth (Cleary et al. 2008). Samples from the PVC cores were soaked for $24 \mathrm{~h}$ in water and then passed through stacked 2-mm and $250-\mu \mathrm{m}$ sieves for $20 \mathrm{~min}$. Material on the sieves was resuspended in water to separate the lightest organic materials $\left(<1 \mathrm{~g} \cdot \mathrm{cm}^{-3}\right)$. Dried material from the $2-\mathrm{mm}$ sieve was separated into live and dead FR, live and dead CR, and LIS. Subsamples of dried material from the $250-\mu \mathrm{m}$ sieve were separated into live and dead FR by picking them apart by hand under a magnifying glass to quantify total mass. Litter was separated into size classes of $\leq 1-\mathrm{cm}$ diameter and $>1-\mathrm{cm}$ diameter. All biomass materials were dried for $48 \mathrm{~h}$ at $60^{\circ} \mathrm{C}$ and weighed. 
Subsamples were ground to a fine powder using a ball mill and combusted in an elemental analyzer (Elementar 2004) to determine C, N, and C:N after ash correction (Cronan 2003). Because of insufficient sample quantities at some depths, mean $\% \mathrm{C}$ and $\% \mathrm{~N}$ contents were used to calculate $\mathrm{C}$ and $\mathrm{N}$ content at all depths.

Soil Organic Carbon. Soil organic carbon (SOC) and total soil nitrogen (TSN) were used to describe $\mathrm{SOM} \leq 2-\mathrm{mm}$ diameter. To determine total soil $\mathrm{C}$ and $\mathrm{N}$, root-free, oven-dried $\left(60^{\circ} \mathrm{C}\right.$ for $48 \mathrm{~h}$ ) bulk soil samples passed through a $2-\mathrm{mm}$ sieve and ground to a fine powder on a roller grinder were combusted in an elemental analyzer (Elementar 2004). Inorganic carbon (IC), determined using the pressure-calcimeter method (Sherrod et al. 2002), was subtracted from total soil C to calculate SOC. Concentrations $\left(\mathrm{mg} \mathrm{C} \cdot \mathrm{g}^{-1}\right.$ soil) were converted to volumes $(\mathrm{kg}$ $\mathrm{C} \cdot \mathrm{m}^{-3}$ soil) using bulk density.

Depth Distributions. Two depth statistics were calculated using cumulative fractions (CF; Jackson et al. 1996; Silva and Rego 2003). The CF of mass at each depth $\left(d_{i}\right)$ were calculated from the surface $\left(d_{0}\right)$ to the deepest sample $\left(d_{j}\right)$, where

$$
\mathrm{CF}_{d i}=\Sigma\left(d_{0} / \Sigma d_{0} \ldots d_{j}\right), \ldots\left(d_{i} / \Sigma d_{0} \ldots d_{j}\right)
$$

The resulting CF series had a value of zero at the surface and one at the maximum depth. The depth above which $50 \%$ of mass was located $\left(\mathrm{D}_{50}\right.$; Leffler et al. 2004) was determined graphically in Sigma Plot 9.01 (Systat 2004). Curvature parameters $(\beta)$ describing exponential decrease of cumulative mass in the profiles were calculated by fitting the model

$$
\mathrm{CF}=1-\beta^{d}
$$

where $d=$ depth (Jackson et al. 1996).

An inventory of soil pool C $\left(\mathrm{g} \mathrm{C} \cdot \mathrm{m}^{-2}\right)$ was calculated by integrating over each depth profile in Sigma Plot 9.01 (Systat 2004). Accumulation rates $\left(\mathrm{g} \mathrm{C} \cdot \mathrm{m}^{-2} \cdot \mathrm{yr}^{-1}\right)$ for above- and belowground pools were estimated by calculating linear slopes between growth stages.

\section{Statistical Methods}

Generalized linear models (GLM) with least-square-means comparisons were used to test for differences unless otherwise noted (SAS 2006). Levene's test for equal variance $(P<0.050)$ was used to determine if transformations were required prior to GLM analyses and retested after transformation to $\log _{10} ; t$ tests were used to compare populations with unequal sample sizes, and $P$-values were significant at $\alpha=0.050$ unless otherwise noted. Standard errors were reported for means unless mean values were summed, in which case standard deviations were estimated using sum of squares.

\section{RESULTS}

\section{Aboveground Carbon Pools and Indices}

Biomass and Indices. Total aboveground biomass increased from 52 to $310 \mathrm{~g} \mathrm{C} \cdot \mathrm{m}^{-2}$ between the recent burn and the mature stages $(P<0.001$; Fig. 1 ; Table 2$)$. It was one of the

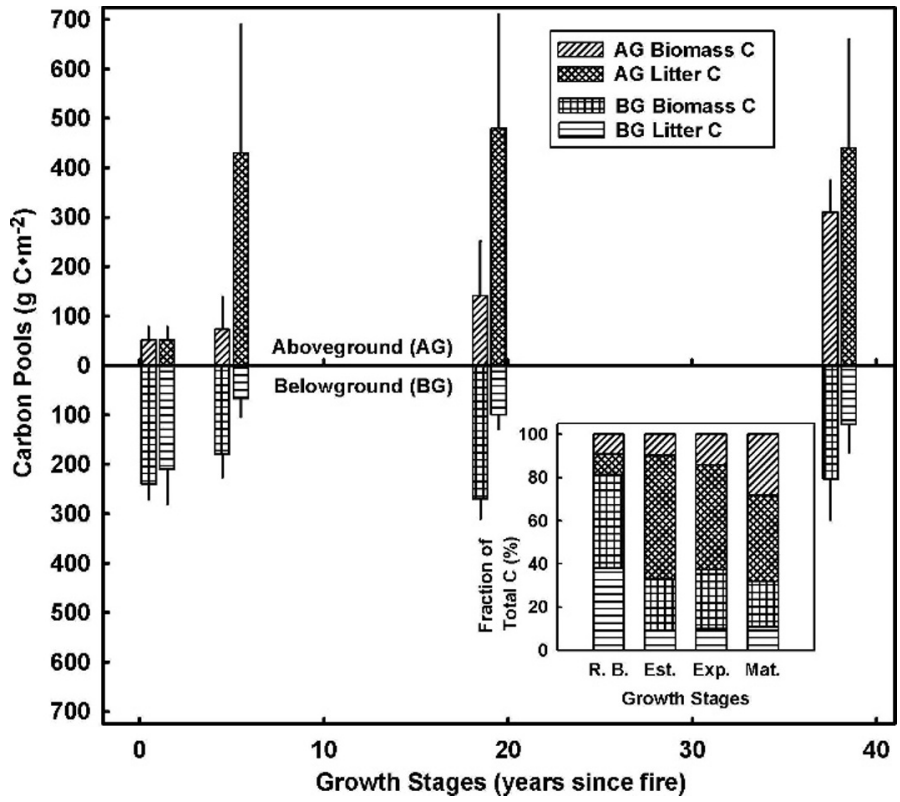

Figure 1. Carbon pools on an areal basis $\left(\mathrm{g} \mathrm{C} \cdot \mathrm{m}^{-2}\right)$ for aboveground biomass (forbs, graminoids, and nonsagebrush shrubs $n=16$, sagebrush shrubs $n=6)$, aboveground litter layer $(n=3)$, belowground biomass (live roots $n=3$ ), and belowground litter (dead roots and aboveground litter incorporated into the soil $n=3$ ) during four growth stages of recovery after fire described by years since fire (ysf; recent burn [R.B., 2 ysf], establishment [Est., 6 ysf], expansion [Exp., 20 ysf], and mature [Mat., $39 \mathrm{ysf}])$. Vertical lines are standard deviations estimated from the sum of squares. Inset depicts the relative contribution of each pool to total ecosystem carbon.

smallest fractions of total ecosystem $\mathrm{C}$ in the first two stages $(9 \%)$ and was the second largest $(28 \%)$ by the mature stage. Graminoids dominated aboveground biomass $(P<0.001)$ during the recent burn stage but decreased as they were first replaced by forbs at the establishment stage $(P=0.060)$ and then by sagebrush at the mature stage $(P<0.001$, Table 2$)$. Forbs were dominant during the establishment stage $(P=$ $0.060)$ and were codominant with graminoids $(P=0.761)$ and sagebrush $(P=0.477)$ during the expansion stage. In the mature stage, graminoids and forbs were reduced to less than one-fourth of their peak biomass values $(P<0.001)$.

Aboveground biomass indices showed distinct trends with time since burning but did not always correlate to comparable aboveground biomass (Table 1). LAI increased $(P<0.001)$, and was correlated with total aboveground biomass (coefficient $=0.969, P=0.031$ ). Percent shrub cover increased $(P=0.011)$ but did not correlate well with increasing total shrub biomass (coefficient $=0.897, P=0.103)$. Percent total cover increased $(P<0.001)$ and correlated with increasing total biomass (coefficient $=0.986, P=0.014)$.

Litter. The total litter layer did not change during recovery after fire $(P=0.463)$ and averaged $350 \pm 100 \mathrm{~g} \mathrm{C} \cdot \mathrm{m}^{-2}$ (Fig. 1). It was one of the smallest fractions of total ecosystem $\mathrm{C}$ at the recent burn $(9 \%)$ and was the largest at all other stages $(40-57 \%)$. The two litter size classes had contrasting patterns that were not comparable to the dynamics of aboveground biomass or biomass indices (Tables 1 and 2). Fine litter $(\leq 1$ $\mathrm{cm}$ diameter) was lowest and the same $(P=0.995)$ at the recent 


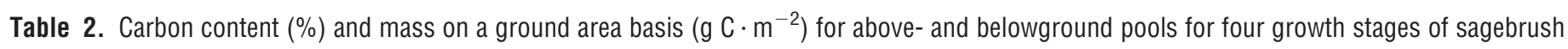
recovery after fire (SE). Carbon content sample sizes were $n=6$ for forbs, graminoids, and sagebrush; $n=12$ for other shrubs; $n=44$ for litter $\leq 1$ $\mathrm{cm}$ diameter; $n=8$ for litter $>1$-cm diameter; and $n=16$ for all belowground pools. Sample size for mass at each growth stage was $n=16$ for forbs, graminoids, and nonsagebrush shrubs; $n=6$ for sagebrush; and $n=3$ for the litter layer and all belowground pools. Letters indicate significant differences between stages $(P<0.05)$; NA $=$ not applicable. Fine roots are $\leq 2-\mathrm{mm}$ diameter, coarse roots are $>2$-mm diameter, and LIS is aboveground litter incorporated into the soil.

\begin{tabular}{|c|c|c|c|c|c|}
\hline \multirow[b]{2}{*}{ Carbon } & \multirow[b]{2}{*}{$\% \mathrm{C}$} & \multicolumn{4}{|c|}{ Mass $\left(\mathrm{g} \mathrm{C} \cdot \mathrm{m}^{-2}\right)$} \\
\hline & & Recent burn & Establishment & Expansion & Mature \\
\hline \multicolumn{6}{|l|}{ Aboveground } \\
\hline Forbs & $47(0.39)$ & $4.2(0.95) \mathrm{a}$ & $51(16) b$ & $51(23) b$ & $12(2.1) a b$ \\
\hline Graminoids & $44(0.41)$ & $48(6.5) \mathrm{c}$ & $22(2.7) b$ & $32(3.0) \mathrm{c}$ & $5.9(1.3) \mathrm{a}$ \\
\hline Nonsagebrush shrubs & $46(0.54)$ & $0.00(0.00) \mathrm{a}$ & $0.00(0.00) \mathrm{a}$ & $3.2(1.7) \mathrm{b}$ & $0.29(0.29) \mathrm{a}$ \\
\hline Sagebrush & $49(0.64)$ & $0.03(0.02) \mathrm{a}$ & $0.31(0.16) \mathrm{a}$ & $55(21) a b$ & $290(26) \mathrm{C}$ \\
\hline Total biomass & NA & $52(26) \mathrm{a}$ & $73(66) \mathrm{a}$ & $141(110) a b$ & $310(64) b$ \\
\hline \multicolumn{6}{|l|}{ Litter layer } \\
\hline$\leq 1$ & $49(0.64)$ & $25(11) a$ & $26(2.8) \mathrm{a}$ & $480(230) \mathrm{b}$ & $420(210) \mathrm{b}$ \\
\hline$>1$ & $49(0.64)$ & $27(27) \mathrm{a}$ & $410(260) \mathrm{b}$ & $0.00(0.00) \mathrm{a}$ & $16(16) \mathrm{a}$ \\
\hline \multicolumn{6}{|l|}{ Belowground } \\
\hline Live fine roots & $53(0.70)$ & $240(18) \mathrm{a}$ & $180(26) \mathrm{a}$ & $270(23) \mathrm{a}$ & $210(47) \mathrm{a}$ \\
\hline Live coarse roots & $53(0.70)$ & $0.00(0.00) \mathrm{a}$ & $0.04(0.02) b$ & $2.7(0.90) \mathrm{C}$ & $17(1.0) d$ \\
\hline Total biomass & NA & $240(31)$ a & $180(46) \mathrm{a}$ & $270(40) \mathrm{a}$ & $230(82)$ a \\
\hline LIS & $57(2.9)$ & $29(19) \mathrm{a}$ & $3.4(0.44)$ a & $36(7.3) \mathrm{a}$ & $29(19) \mathrm{a}$ \\
\hline Dead fine roots & $57(2.9)$ & $80(13) b$ & $33(8.5) \mathrm{ab}$ & $20(8.6) \mathrm{a}$ & $40(9.0) a b$ \\
\hline Dead coarse roots & $57(2.9)$ & $100(32) \mathrm{a}$ & $31(20) \mathrm{a}$ & $49(12) \mathrm{a}$ & $51(24) \mathrm{a}$ \\
\hline \multicolumn{6}{|l|}{ Ecosystem } \\
\hline Biomass & $N A$ & $290(40)$ a & $250(80)$ a & 410 (110) ab & $530(100) \mathrm{b}$ \\
\hline Total & NA & $550(110) \mathrm{a}$ & $750(650)$ a & $1040(580) \mathrm{a}$ & $1100(530) \mathrm{a}$ \\
\hline
\end{tabular}

burn and establishment stages and peaked at the expansion and mature stages $(P=0.071)$, where it was dominated by sagebrush leaves and twigs. Coarse litter $(>1-\mathrm{cm}$ diameter) was not significantly different between the recent burn and mature stages $(P=0.952)$, peaked at the establishment stage $(P=0.059)$, and was not documented at the expansion stage.

\section{Belowground Carbon Pools}

Biomass. Total live root biomass was static over the growth stages at $230 \pm 58 \mathrm{~g} \mathrm{C} \cdot \mathrm{m}^{-2}$ and was the largest fraction of total ecosystem $\mathrm{C}$ at the recent burn $(43 \%)$ and the second smallest by the mature stage $(21 \%$; Fig. 1$)$. It was dominated by the live FR pool, which was not different among growth stages $(P=0.254)$ and averaged $230 \pm 17 \mathrm{~g} \mathrm{C} \cdot \mathrm{m}^{-2}$ (Table 2$)$. Depth distributions $\left(\mathrm{D}_{50}\right.$ and $\left.\beta\right)$ of live FR did not change during recovery and, along with dead FR, were the shallowest and second steepest (Fig. 2). Starting at the establishment stage, live CR increased $(P=0.005$; Table 2$)$. Live FR:live CR tended to decrease but not significantly $(P=0.280$; Table 3$)$. The ratios of total live roots:total dead roots and live FR:dead FR were highest at the expansion stage $(P=0.076$ and 0.064 , respectively). Although the highest live CR:dead CR was at the expansion stage, the ratio did not change during recovery $(P=0.496)$.

Relationships to Aboveground Biomass and Indices. Live root:total aboveground biomass ratios decreased from the recent burn stage to the mature stage because live roots did not change with growth stage $(P>0.100)$, while aboveground biomass increased (Fig. 1; Table 3). Live CR were calculated using allometric relationships of aboveground sagebrush biomass; they therefore correlated to sagebrush biomass and indices that also correlated to sagebrush biomass. Total aboveground biomass, LAI, shrub cover, and total cover increased during recovery and, therefore, correlated significantly with growth stages (years since fire) and each other (0.050 > P $>0.010$; Table 4).

Litter. Total belowground litter (LIS and dead roots) was highest at the recent burn $\left(210 \pm 70 \mathrm{~g} \mathrm{C} \cdot \mathrm{m}^{-2}\right)$ and lowest at the establishment stage $\left(67 \pm 37 \mathrm{~g} \mathrm{C} \cdot \mathrm{m}^{-2}\right.$; Fig. 1). It made up the second-largest fraction of total ecosystem $\mathrm{C}$ at the recent burn $(38 \%)$ and was the smallest at all other stages $(8.9-11 \%)$. The LIS pool averaged $24 \pm 7 \mathrm{~g} \mathrm{C} \cdot \mathrm{m}^{-2}$ and did not change across the four growth stages $(P=0.410$; Table 2$)$. Dead FR and dead CR peaked at the recent burn stage, were lowest in the intermediate growth stages, and increased slightly during the mature stage. Dead FR were the shallowest and secondsteepest pool, along with live FR (Fig. 2). Dead CR had the second-deepest $\mathrm{D}_{50}$ and a similar $\beta$ value as live FR, and its high variability precluded detecting patterns across growth stages. Dead FR decreased $(P=0.005)$, but dead CR did not $\left(P=0.277\right.$; mean $\left.58 \pm 13 \mathrm{~g} \mathrm{C} \cdot \mathrm{m}^{-2}\right)$; however, dead FR:dead CR ratios at all growth stages were similar $(P>0.05$; Table 3$)$.

Soil Organic Carbon. The total pool of SOC to 1.8-m depth was marginally higher $(P=0.063)$, and the total TSN pool was 
A) Live Fine Root
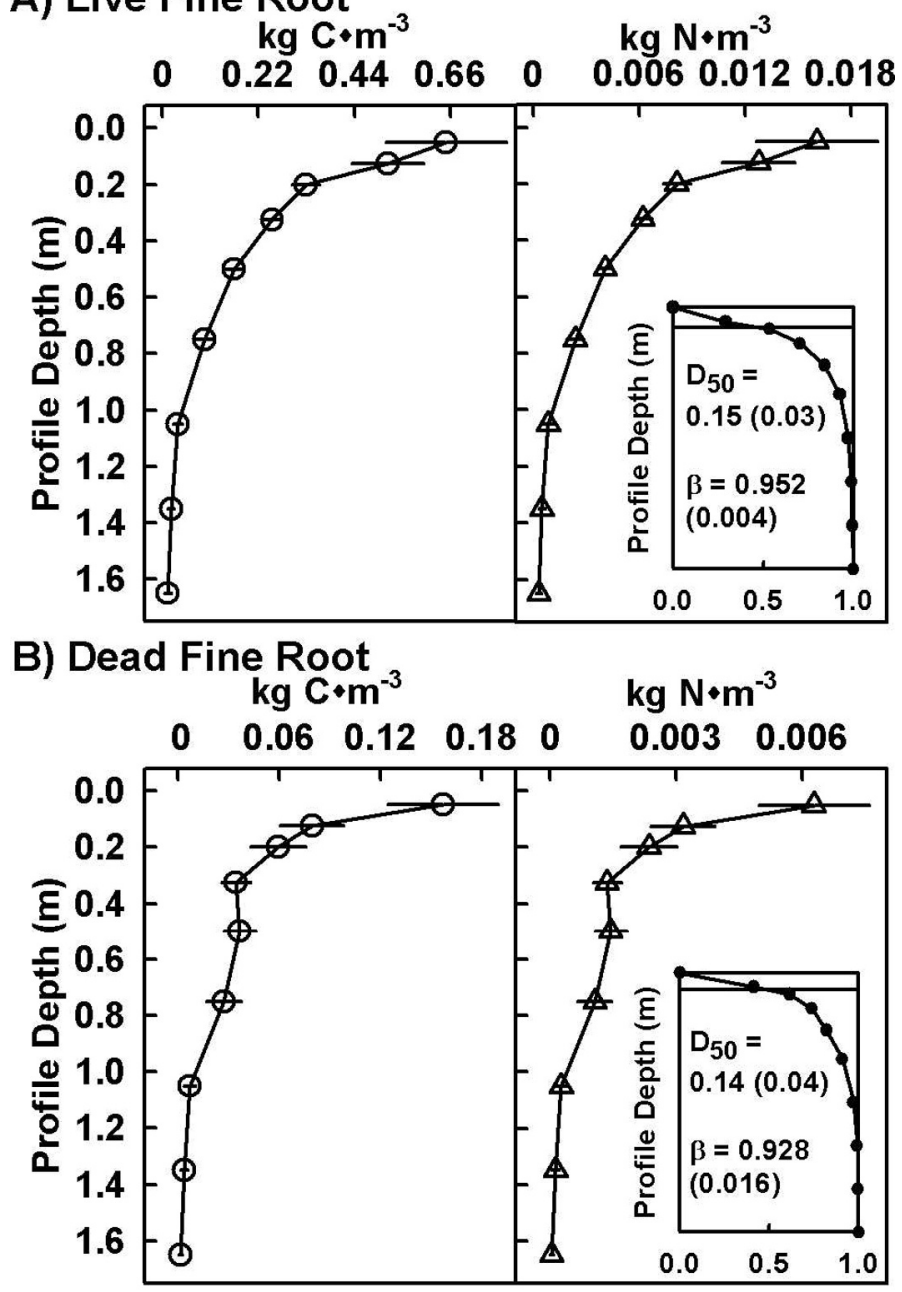

C) Dead Coarse Root

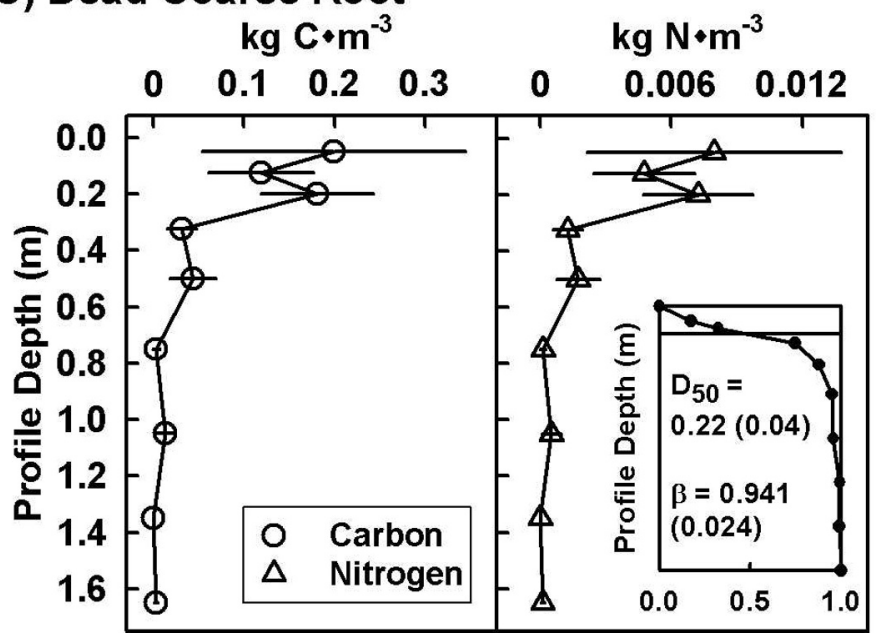

Figure 2. Depth profiles depict mean $\mathrm{C}$ and $\mathrm{N}$ content of $\mathbf{A}$, live fine roots, $\mathbf{B}$, dead fine roots, and $\mathbf{C}$, dead coarse roots for all four stages of recovery after fire combined. Insets depict means of cumulative fractions by depth with their $D_{50}$ (depth above which $50 \%$ of mass is located, in $\mathrm{m}$ ) and $\beta$ values (curvature parameters describing exponential decreases). Horizontal lines and values in parentheses are SE $(n=12)$. significantly higher $(P=0.005)$ in the sandier soils at the recent burn $\left(16 \pm 1.8 \mathrm{~kg} \mathrm{C} \cdot \mathrm{m}^{-2}, 1.4 \pm 0.09 \mathrm{~kg} \mathrm{~N} \cdot \mathrm{m}^{-2}\right)$ and expansion $\left(17 \pm 0.46 \mathrm{~kg} \mathrm{C} \cdot \mathrm{m}^{-2}, 1.4 \pm 0.06 \mathrm{~kg} \mathrm{~N} \cdot \mathrm{m}^{-2}\right)$ stages than at the establishment $\left(11 \pm 1.8 \mathrm{~kg} \mathrm{C} \cdot \mathrm{m}^{-2}, 1.0 \pm 0.08 \mathrm{~kg} \mathrm{~N} \cdot \mathrm{m}^{-2}\right)$ and mature $\left(11 \pm 2.3 \mathrm{~kg} \mathrm{C} \cdot \mathrm{m}^{-2}, 0.81 \pm 0.13 \mathrm{~kg} \mathrm{~N} \cdot \mathrm{m}^{-2}\right)$ stages. Depth profiles of SOC and TSN did not change among growth stages (Fig. 3); for both SOC and TSN, $\mathrm{D}_{50}$ values were the deepest, and $\beta$ values were the least steep of all the pools.

\section{Rates of C Accumulation or Loss}

Total ecosystem $\mathrm{C}$ accumulation (live and dead biomass) was $15 \mathrm{~g}$ $\mathrm{C} \cdot \mathrm{m}^{-2} \cdot \mathrm{yr}^{-1}$, and biomass $\mathrm{C}$ accumulation (living biomass) was $6.5 \mathrm{~g} \mathrm{C} \cdot \mathrm{m}^{-2} \cdot \mathrm{yr}^{-1}$ between the recent burn and mature stages (Table 2). Accumulation rates of aboveground biomass and fine litter were estimated at 7.0 and $11 \mathrm{~g} \mathrm{C} \cdot \mathrm{m}^{-2} \cdot \mathrm{yr}^{-1}$, respectively. Total $\mathrm{C}$ accumulation rates were highest between the recent burn and establishment stages $\left(50 \mathrm{~g} \mathrm{C} \cdot \mathrm{m}^{-2} \cdot \mathrm{yr}^{-1}\right)$, slowing to $21 \mathrm{~g}$ $\mathrm{C} \cdot \mathrm{m}^{-2} \cdot \mathrm{yr}^{-1}$ between the establishment and expansion stages and to $3.2 \mathrm{~g} \mathrm{C} \cdot \mathrm{m}^{-2} \cdot \mathrm{yr}^{-1}$ between the expansion and mature stages. Biomass $\mathrm{C}$ was lost between the recent burn and establishment stages $\left(-10 \mathrm{~g} \mathrm{C} \cdot \mathrm{m}^{-2} \cdot \mathrm{yr}^{-1}\right)$ because of fewer live graminoids and FR. Biomass $\mathrm{C}$ accumulated the fastest between the establishment and expansion stages $\left(11 \mathrm{~g} \mathrm{C} \cdot \mathrm{m}^{-2} \cdot \mathrm{yr}^{-1}\right)$ and accumulated more slowly between the expansion and mature stages $\left(6.3 \mathrm{~g} \mathrm{C} \cdot \mathrm{m}^{-2} \cdot \mathrm{yr}^{-1}\right)$.

\section{C:N Ratios}

The C:N did not change among growth stages $(P>0.403)$ except for live CR. The mass of $\mathrm{C}$ in live $\mathrm{CR}$ increased faster than $\mathrm{N}$, resulting in an increase $(P=0.054)$ in $\mathrm{C}: \mathrm{N}$ between the establishment $(31 \pm 4.4)$ and mature $(120 \pm 14)$ stages. Aboveground C: $\mathrm{N}$ was lowest for leaves of L. argenteus, a nitrogenfixing plant $(11 ; P=0.000$; Fig. 4A). Leaves of $P$. smithii had lower C:N (27) than sagebrush leaves $(34 ; P=0.003)$, and sagebrush leaves had similar $\mathrm{C}: \mathrm{N}$ to sagebrush inflorescences (37; $P=0.266)$. New stem growth and wood $\leq 1$-cm diameter had similar C:N (61 and 66, respectively; $P=0.291$ ) that was higher than leaves and inflorescences. Wood $>1-\mathrm{cm}$ diameter had the highest $\mathrm{C}: \mathrm{N}(109 ; P=0.020)$. Belowground C:N decreased over the decay continuum $(P<0.010)$ from live $\mathrm{CR}$ (85) to live FR (41) to dead roots (25 and 26) and LIS (26) to SOC:TSN (12; Fig. 4B). Dead root and LIS C:N were not different $(P=0.325)$.

\section{DISCUSSION}

Biomass $\mathrm{C}$ accumulation in this mountain big sagebrush ecosystem was almost entirely explained by shrub growth aboveground, in contrast to other semiarid woody ecosystems where roots drive C accumulation (Hibbard et al. 2001). Because there is more accumulation aboveground, there is potential for larger $\mathrm{C}$ loss when fire occurs. The fastest rate of biomass accumulation occurred early in succession; total $\mathrm{C}$ and biomass $\mathrm{C}$ accumulation peaked between 6 and $20 \mathrm{yr}$ since fire. The lack of accumulation belowground is partially due to live root biomass and SOC remaining nearly constant despite aboveground biomass and fine litter layer increases. Live root biomass was static primarily because of perennial grass FR that 
Table 3. Ratios of aboveground biomass ( $A G$ ), live and dead fine roots ( $F R, \leq 2-\mathrm{mm}$ diameter), and live and dead coarse roots (CR, $>2$-mm diameter) for four sagebrush growth stages during recovery after fire (SE). Letters indicate significant differences between stages $(P<0.08)$, and $\mathrm{NA}=$ not applicable because there were no live coarse roots.

\begin{tabular}{|c|c|c|c|c|}
\hline & \multicolumn{4}{|c|}{ Growth stages } \\
\hline & Recent burn & Establishment & Expansion & Mature \\
\hline Live roots:total $A G$ & 3.9 & 2.1 & 1.8 & 0.68 \\
\hline Live FR:live CR & NA & $39(32) \mathrm{a}$ & $18(16) \mathrm{a}$ & $4.6(2.3) \mathrm{a}$ \\
\hline Dead FR:dead CR & $0.9(0.27) \mathrm{a}$ & $1.8(0.52) \mathrm{a}$ & $0.6(0.4) \mathrm{a}$ & $1.3(0.56) \mathrm{a}$ \\
\hline Live roots:dead roots & $1.7(0.48) \mathrm{a}$ & $3.9(0.99)$ ab & $6.4(1.9) \mathrm{b}$ & $4.4(2.4) \mathrm{ab}$ \\
\hline Live FR:dead FR & $3.6(0.72) \mathrm{a}$ & $6.2(0.86) \mathrm{a}$ & $23(10) b$ & $6.4(2.1) \mathrm{a}$ \\
\hline Live CR:dead CR & NA & $0.37(0.30) \mathrm{a}$ & $4.0(3.4) \mathrm{a}$ & $3.3(2.6) \mathrm{a}$ \\
\hline
\end{tabular}

survived the fire and likely capitalized on newly mineralized nutrients to expedite aboveground graminoid growth within weeks of being burned. The persistence of the graminoid roots may help explain previous findings that aboveground biomass increases rapidly after fire and is resilient to spring and summer grazing for at least the first $3 \mathrm{yr}$ after burning (Bates et al. 2009).

\section{Aboveground Carbon Pools and Indices}

Peak aboveground biomass in the mature stage $\left(330 \mathrm{~g} \mathrm{C} \cdot \mathrm{m}^{-2}\right)$ is similar to the range $\left(440 \pm 180 \mathrm{~g} \mathrm{C} \cdot \mathrm{m}^{-2}\right)$ for Great Basin sagebrush steppe (Bradley et al. 2006). Aboveground biomass shifted to sagebrush dominance within $39 \mathrm{yr}$ (Table 2), similar to the 32-yr recovery reported by Lesica et al. (2007). Although forb and graminoid cover decreased with increasing sagebrush biomass, deeply rooted, perennial bunchgrasses such as Hesperostipa, Poa, and Elymus spp. persisted in mature stands. Their persistence and dense regrowth after fire may be a mechanism providing resilience to fire and grazing soon after fire (Anderson and Inouye 2001; Davies et al. 2008; Bates et al. 2009).

Table 4. Relationships between belowground biomass pools and aboveground biomass pools and indices. Growth stage correlations used actual years since fire. Coefficients were significant when noted, where ${ }^{* * *}=$ highly significant $(P \leq 0.005),{ }^{* *}=$ significant $(0.05>$ $P>0.005)$, and ${ }^{*}=$ moderately significant $(0.1>P \geq 0.050) . \mathrm{FR}=$ fine roots, $\mathrm{CR}=$ coarse roots, $\mathrm{NA}=$ not applicable, and $\mathrm{LAI}=$ leaf area index.

\begin{tabular}{lccc}
\hline & $\begin{array}{c}\text { Live FR biomass } \\
\left(\mathrm{g} \cdot \mathrm{m}^{-2}\right)\end{array}$ & $\begin{array}{c}\text { Live CR biomass } \\
\left(\mathrm{g} \cdot \mathrm{m}^{-2}\right)\end{array}$ & $\begin{array}{c}\text { Growth } \\
\text { stage }\end{array}$ \\
\hline Growth stage & 0.001 & $0.942^{*}$ & $\mathrm{NA}$ \\
Aboveground biomass $\left(\mathrm{g} \cdot \mathrm{m}^{-2}\right)$ & & \\
$\quad$ Forbs & -0.080 & -0.406 & -0.148 \\
Graminoids & 0.559 & -0.800 & -0.804 \\
Nonsagebrush shrubs & 0.734 & -0.114 & 0.214 \\
Sagebrush & -0.144 & $0.999^{\star * *}$ & $0.955^{\star *}$ \\
Total biomass & -0.060 & $0.964^{* *}$ & $0.997^{\star *}$ \\
Aboveground biomass indices & & & \\
LAl (m $\left.{ }^{2} \cdot \mathrm{m}^{-2}\right)$ & -0.025 & $0.980^{\star * 1}$ & $0.980^{\star *}$ \\
Shrub cover $(\%)$ & 0.179 & $0.966^{\star * 1}$ & $0.982^{\star *}$ \\
Total cover $(\%)$ & 0.060 & $0.843^{1}$ & $0.996^{\star * *}$ \\
\hline
\end{tabular}

${ }^{1} \log _{10}$ transformations used to calculate coefficients.
The litter layer was the largest and most variable $\mathrm{C}$ pool. Accumulation of a substantial fine litter pool $20 \mathrm{yr}$ after burning may be explained primarily by contributions of sagebrush leaves, which decompose more slowly than forb and graminoid litter (Shaw and Harte 2001). More extensive sampling and separation of burnt stumps would improve estimates of coarse litter (Yanai et al. 2003). Total litter did not increase with aboveground biomass; it accumulated rapidly after fire and remained relatively constant, similar to the pattern found by Covington (1981) following forest harvest.

\section{Belowground Carbon Pools}

Live FR dominated root biomass and remained relatively constant (Table 2). It is likely that a substantial portion of FR were from sagebrush at the mature stage (Sturges 1977), but the presence of perennial grasses with deep minimum rooting depths (0.3-0.5 m; US Department of Agriculture, Natural Resources Conservation Service 2007) may maintain substantial live FR biomass even when their aboveground biomass declines. The maintenance of live FR by grasses, as well as rapid regrowth of sagebrush roots, may explain the higher than expected live FR biomass at the recent burn stage and the relatively constant live FR biomass during recovery. Live FR biomass on an areal basis $\left(0.43 \pm 0.03 \mathrm{~kg} \cdot \mathrm{m}^{-2}\right)$ was double that reported for big sagebrush in southern Colorado $\left(0.21 \mathrm{~kg} \cdot \mathrm{m}^{-2}\right.$ integrated to $1.8-\mathrm{m}$ depth) with lower annual precipitation $\left(<230 \mathrm{~mm} \mathrm{yr}^{-1}\right.$; Branson et al. 1976) and was one-third what was reported for semiarid shrub ecosystems in Mexico $\left(0.60 \mathrm{~kg} \cdot \mathrm{m}^{-2}\right.$ integrated to $0.5-\mathrm{m}$ depth) that received almost twice as much precipitation (565 $\mathrm{mm} \mathrm{yr}^{-1}$; Pavón 2005). These results suggest that mean annual precipitation may also influence the amount of total live root biomass produced, as it does for net aboveground primary productivity in grasslands and shrublands across North America (Knapp et al. 2008).

Lack of live FR dynamics in sagebrush steppe contrasts with predictable increases in live FR during succession in some temperate and tropical forests (Yin et al. 1989; Vargas et al. 2008). However, stable live FR and increasing CR with increasing aboveground woody biomass, as we found in this study, were also found for a northern temperate forest chronosequence that had repeated fires and harvesting (Gough et al. 2007). The magnitude of increasing live CR in this study was underestimated because of sampling limited to $0.25-\mathrm{m}$ depth. Total live CR mass is likely to be greater if CR follow a similar depth trajectory as we found for dead CR (Fig. 2). 


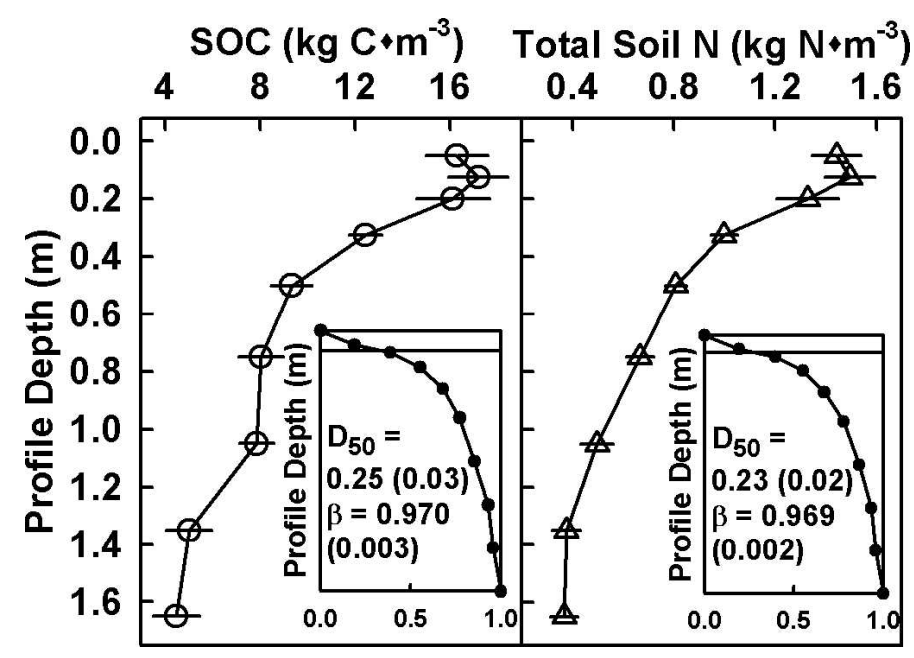

Figure 3. Depth profiles depict mean total soil organic carbon (SOC) and total soil nitrogen (N) for all stages of recovery after fire combined. Insets depict means of cumulative fractions by depth with their $D_{50}$ (depth above which $50 \%$ of mass is located, in $\mathrm{m}$ ) and $\beta$ values (curvature parameters describing exponential decreases). Horizontal lines and values in parentheses are SE $(n=12)$.

The exponential decline in live FR biomass with depth regardless of time since disturbance was consistent with sagebrush in Colorado (Branson et al. 1976); Mediterranean shrublands in Portugal (Silva and Rego 2003); and semiarid scrublands in Mexico (Pavón 2005). Sagebrush root distributions were similar to sclerophyllous shrubs worldwide, with $67-79 \%$ of live FR biomass located above $0.30 \mathrm{~m}$ and $\beta$-values between 0.950 and 0.964 (Jackson et al. 1996, 1997). The $D_{50}$ for sagebrush ecosystem live FR $(0.15 \mathrm{~m})$ was almost identical to what Schenk and Jackson (2002) reported for semiarid steppe $(0.16 \mathrm{~m})$, which suggests there are consistent rooting patterns across semiarid shrub ecosystems worldwide.

The ratio of live roots:aboveground biomass (1-4) in this study was similar to the root:shoot (R:S) ratios reported for sclerophyllous shrub $(0.3-5)$, deserts $(0.7-4.5)$, and temperate grasslands (3.7; Table 3; Jackson et al. 1996). Total root biomass in the top $0.10 \mathrm{~m}$ in this study $\left(1.2 \pm 0.26 \mathrm{~kg} \cdot \mathrm{m}^{-3}\right)$ was half what Branson et al. (1976) reported for basin big sagebrush (Artemisia tridentata Nutt. subsp. tridentata) in Colorado $\left(\sim 2.4 \mathrm{~kg} \cdot \mathrm{m}^{-3}\right)$. Basin big sagebrush has less aboveground biomass per shrub and is found at lower elevations with less precipitation than mountain big sagebrush (Frisina and Wambolt 2004). To thrive in drier climates, basin big sagebrush maintains higher $\mathrm{R}: \mathrm{S}$ than mountain big sagebrush (Kolb and Sperry 1999). Although FR biomass could not be estimated using aboveground measurements (Table 4), sampling to $0.15-\mathrm{m}$ depth was sufficient to estimate $50 \%$ of live FR biomass (Fig. 2A). Live CR mass was strongly correlated to aboveground biomass because it was calculated using allometric relationships of aboveground biomass ( $\mathrm{Ta}-$ ble 4).

The highest dead root mass occurred in the recent burn stage because dominant, mature shrub roots were killed during the fire and likely decomposed as the ecosystem recovered (Table 2). Changes in dead roots owing to decomposition during recovery were not apparent in this study, possibly

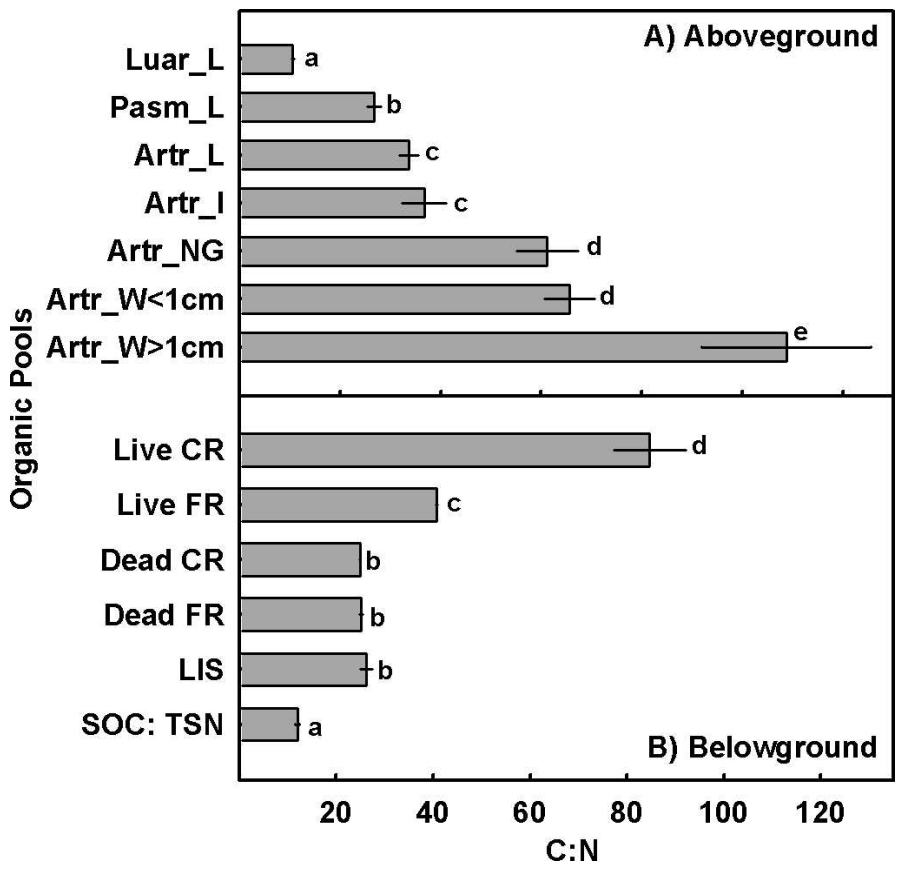

Figure 4. Carbon to nitrogen $(\mathrm{C}: \mathrm{N})$ ratios of $\mathbf{A}$, aboveground and $\mathbf{B}$, belowground pools. Aboveground pools include Lupinus argenteus leaves (Luar_L; $n=6$ ), Pascopyrum smithii leaves (Pasm_L; $n=6$ ), Artemisia tridentata leaves (Artr_L; $n=22$ ), inflorescences (Artr_l; $n=8$ ), new stem growth (Artr_NG; $n=10$ ), wood $\leq 1$-cm diameter (Artr_W $<1 \mathrm{~cm} ; n=10$ ), and wood $>1-\mathrm{cm}$ diameter (Artr_W $>1 \mathrm{~cm}$; $n=8)$. Soil pools $(n=12)$ include live coarse roots $(C R)$, live fine roots (FR), dead CR, dead FR, aboveground litter incorporated into soil (LIS), and soil organic carbon:total soil nitrogen (SOC:TSN). Horizontal lines indicate standard errors, and small letters indicate significant differences.

because the belowground root pools were close to steady state or because of high variability within each stage. Dead CR mass was generally greater than dead FR mass, suggesting that CR decomposed more slowly and therefore immobilized $\mathrm{C}$ for longer periods than FR (Lehmann et al. 1995). The mountain big sagebrush live:dead root ratio was much higher (1.7-6.4) than for sclerophyllous shrubs (0.54; Jackson et al. 1997), suggesting higher root turnover rates in sagebrush than sclerophyllous shrub ecosystems.

Soil Organic Carbon. Soils in this study had about $20 \mathrm{~g}$ SOC $\cdot \mathrm{kg}$ soil $^{-1}$ and $1.7 \mathrm{~g} \mathrm{TSN} \cdot \mathrm{kg} \mathrm{soil}{ }^{-1}$ in the top $0.15 \mathrm{~m}$, which was similar to a sagebrush community in Washington (12 $\mathrm{g} \mathrm{C}$ and $2.2 \mathrm{~g} \mathrm{~N} \cdot \mathrm{kg} \mathrm{soil}^{-1}$; Bolton et al. 1993), and a Wyoming big sagebrush (Artemisia tridentata Nutt. subsp. wyomingensis Beetle and Young) community in Utah (14 g C and $1.4 \mathrm{~g} \mathrm{~N} \cdot \mathrm{kg} \mathrm{soil}^{-1}$; Saetre and Stark 2005). Substantial soil $\mathrm{C}$ accumulation in mollic horizons is indicative of grasslands, suggesting that these areas have burned on a regular basis at a fire interval of 10-50 yr (Baker 2006). Some of the C accumulation was probably partially a result of char accumulation that is estimated at $4-17 \%$ of SOM in North American prairie soil and may increase ecosystem stability and resilience (Knicker 2007). Lack of SOC differences during recovery $(P>0.050)$ was consistent with the Wyoming and basin big sagebrush varieties in Oregon (Acker 1992). Carbon accumulated in dead biomass more rapidly than in live biomass during 
succession, and although some of the dead biomass would eventually transfer to SOC, our measurements did not resolve changes in SOC during succession. This study found $17 \%$ of SOC between $0.9 \mathrm{~m}$ and $1.8 \mathrm{~m}$ (Fig. 3), demonstrating that measurements past 1.0-m depth are not needed to capture the majority of SOC in semiarid shrub ecosystems (Lorenz and Lal 2005).

\section{C:N Ratios}

C:N values were constant across growth stages, suggesting that the same C: $\mathrm{N}$ value for each pool at any stage can be used in $\mathrm{C}$ cycling models (Paustian et al. 1992; Thornley and Cannell 1997). Aboveground C:N values increased predictably from low values in leaves and inflorescences (11-34) that require higher $\mathrm{N}$ for metabolism to increasingly higher values in new stems and wood (66-109) that require $\mathrm{C}$ for long-term structure and stability (Fig. 4). Litter layer accumulation was primarily sagebrush leaves and twigs because they contain higher lignin: $\mathrm{N}$ than graminoid and forb leaves and are more resilient to decomposition (Shaw and Harte 2001).

Belowground C:N changes reflect the loss of $\mathrm{C}$ during decomposition as $\mathrm{C}: \mathrm{N}$ decreased from live root biomass (4181) to litter (26) and SOM (12). Other reports of soil organic C:N ratios for sagebrush were also low; Saetre and Stark (2005) reported a C:N ratio of 10 in Utah, and Smith et al. (2002) reported C:N ratios of 4-16 in Washington. The C:N decrease from live wood (66-109) to dead (26) to soil organic matter (12) in this study was similar to loblolly pine forest vegetation, where $\mathrm{C}: \mathrm{N}$ decreased from live wood (330-380) to litter (39-53) to soil (15-21; Johnson et al. 2003). The predictable changes in $\mathrm{C}: \mathrm{N}$ values based on plant part and soil pool strengthens the validity of the decay continuum concept (Melillo et al. 1989) and supports the use of C:N ratios for distinguishing between organic pools.

\section{IMPLICATIONS}

Recently burned sagebrush steppe is dominated by graminoids and forbs and supports less aboveground biomass $\mathrm{C}$ but similar belowground biomass $\mathrm{C}$ compared with areas where sagebrush have recovered after fire. Therefore, $\mathrm{C}$ accumulates on the landscape primarily because of aboveground shrub growth and a rapidly increasing litter layer. The persistence and rapid regrowth of perennial bunchgrasses with substantial roots that not only survive the fire but also likely capitalize on the newly mineralized nutrients resultant from burning may explain the resilience and speed at which mountain big sagebrush communities reestablish after fire. Detectable increases in aboveground $\mathrm{C}$ storage are not likely to increase past the amount at the mature stage.

\section{ACKNOWLEDGMENTS}

Thanks to I. Abernethy, M. Bell, B. Cline, C. Miller, D. Sackett, and A. Schulstad for assistance with data collection and processing. Thanks to C. Newberry and G. Soehn (BLM), B. Budd and J. Ward (Nature Conservancy), and K. Brauneis (Forest Service) for assistance in locating appropriate field sites and D. Stratton and S. Scott for access to their grazing allotments and private lands.

\section{LITERATURE CITED}

ACkeR, S. A. 1992. Wildfire and soil organic-carbon in sagebrush-bunchgrass vegetation. Great Basin Naturalist 52:284-287.

Anderson, J. E., And R. S. Inouye. 2001. Landscape-scale changes in plant species abundance and biodiversity of a sagebrush steppe over 45 years. Ecological Monographs 71:531-556.

Baker, W. L. 2006. Fire and restoration of sagebrush ecosystems. Wildlife Society Bulletin 34:177-185.

Bates, J. D., E. C. Rhodes, K. W. Davies, and R. Sharp. 2009. Postfire succession in big sagebrush steppe with livestock grazing. Rangeland Ecology \& Management 62:98-110.

Boeken, B., and D. Orenstein. 2001. The effect of plant litter on ecosystem properties in a Mediterranean semi-arid shrubland. Journal of Vegetation Science 12:825-832.

Bolton, H., J. L. Smith, And S. O. Link. 1993. Soil microbial biomass and activity of a disturbed and undisturbed shrub-steppe ecosystem. Soil Biology and Biochemistry 25:545-552.

Bradley, B. A., R. A. Houghton, J. F. Mustard, and S. P. Hamburg. 2006. Invasive grass reduces aboveground carbon stock in shrublands of the Western U.S. Global Change Biology 12:1815-1822.

Branson, F. A., R. F. Miller, and I. S. McQueen. 1976. Moisture relationships in 12 northern desert shrub communities near Grand Junction, Colorado. Ecology 57:1104-1124.

Chapin, F. S., P. A. Matson, and H. A. Mooney. 2002. Principles of terrestrial ecosystem ecology. New York, NY, USA: Springer. $436 \mathrm{p}$.

Chen, J., And J. M. Stark. 2000. Plant species effects and carbon and nitrogen cycling in a sagebrush-crested wheatgrass soil. Soil Biology and Biochemistry 32:47-57.

Cleary, M. B., E. Pendall, and B. E. Ewers. 2008. Testing sagebrush allometric relationships across three fire chronosequences in Wyoming, USA. Journal of Arid Environments 72:285-301.

Covington, W. W. 1981. Changes in the forest floor organic matter and nutrient content following clear cutting in northern hardwoods. Ecology 62:41-48.

Cronan, C. S. 2003. Belowground biomass, production, and carbon cycling in mature Norway spruce, Maine, USA. Canadian Journal of Forest Research 33:339-350.

Davies, K. W., S. Sheley, and J. D. Bates. 2008. Does prescribed fall burning Artemisia tridentata steppe promote invasion or resisance to invasion after a recovery period? Journal of Arid Environments 72:1076-1055.

Donovan, L. A., and J. R. Ehleringer. 1994. Water-stress and use of summer precipitation in a great basin shrub community. Functional Ecology 8:289297.

Elementar. 2004. Vario macro elemental analyzer. Mount Laurel, NJ, USA: Elementar Americas, Inc.

Ewers, B. E., and E. Pendall. 2008. Spatial patterns in leaf area and plant functional type cover across chronosequences of sagebrush ecosystems. Plant Ecology 194:67-83.

Foster, B. L., And D. Tilman. 2000. Dynamic and static views of succession: testing the descriptive power of the chronosequence approach. Plant Ecology 146:1-10.

Frisina, M. R., And C. L. Wambolt. 2004. Keying in on big sagebrush. Rangelands 26:12-16.

GLOBE. 2005. The GLOBE program teacher's guide: soil chapter-soil particle size distribution. Available at: http://www.globe.gov/tctg/tctoc.jsp. Accessed 15 May 2005.

Gough, C. M., C. S. Vogel, K. H. Harrold, K. George, and P. S. Curtis. 2007. The legacy of harvest and fire on ecosystem carbon storage in a north temperate forest. Global Change Biology 13:1935-1949.

Harniss, R. O., and R. B. MurRay. 1973. Thirty years of vegetal change following burning of sagebrush/grass range. Journal of Range Management 26: 322-325.

Hibbard, K. A., S. Archer, D. S. Schimel, and D. W. Valentine. 2001. Biogeochemical changes accompanying woody plant encroachment in a subtropical savanna. Ecology 82:1999-2011. 
Jackson, R. B., J. L. Banner, E. G. Jobbágy, W. T. Pockman, and D. H. Wall. 2002. Ecosystem carbon loss with woody plant invasion of grasslands. Nature 418:623-626.

Jackson, R. B., J. Canadell, J. R. Ehleringer, H. A. Mooney, 0. E. Sala, and E. D. Schulze. 1996. A global analysis of root distributions for terrestrial biomes. Oecologia 108:389-411.

Jackson, R. B., H. A. Mooney, and E. D. Schulze. 1997. A global budget for fine root biomass, surface area, and nutrient contents. Proceedings of the National Academy of Sciences of the United States of America 94:7362-7366.

JobBágy, E. G., And R. B. Jackson. 2000. The vertical distribution of soil organic carbon and its relation to climate and vegetation. Ecological Applications 10:423-436

Johnson, D. W., D. E. Todd, JR., And V. R. Tolbert. 2003. Changes in ecosystem carbon and nitrogen in a loblolly pine plantation over the first 18 years. Soil Science Society of America Journal 67:1594-1601.

Johnson, E. A., AND K. Miranishi. 2008. Testing the assumptions of chronosequence in succession. Ecology Letters 11:419-431.

Knapp, A. K., J. M. Briggs, S. L. Collins, S. R. Archer, M. S. Bret-Harte, B. E. Ewers, D. P. Peters, D. R. Young, G. R. Shaver, E. Pendall, and M. B. Cleary. 2008. Shrub encroachment in North American grasslands: shifts in growth form dominance rapidly alters control of ecosystem carbon inputs. Global Change Biology 14:615-623.

KNICKER, H. 2007. How does fire affect the nature and stability of soil organic nitrogen and carbon? A review. Biogeochemistry 85:91-118.

Kolb, K. J., and J. S. SperRy. 1999. Differences in drought adaptation between subspecies of sagebrush (Artemisia tridentata). Ecology 22:925-935.

Law, B. E., O. J. Sun, J. Campbell, S. Van Tuyl, and P. E. Thornton. 2003. Changes in carbon storage and fluxes in a chronosequence of ponderosa pine. Global Change Biology 9:510-524.

Leffler, A. J., C. Y. Ivans, R. J. Ryel, and M. M. Caldwell. 2004. Gas exchange and growth responses of the desert shrubs Artemisia tridentata and Chrysothamnus nauseosus to shallow- vs. deep-soil water in a glasshouse experiment. Environmental and Experimental Botany 51:9-19.

Lehmann, J., G. Schroth, and W. Zech. 1995. Decomposition and nutrient release from leaves, twigs, and roots of three alley-cropped tree legumes in central Togo. Agroforestry Systems 29:21-36.

Lesica, P., S. V. COOPER, AND G. KudRay. 2007. Recovery of big sagebrush following fire in southwest Montana. Rangeland Ecology \& Management 60:261-269.

Lorenz, K., AND R. LaL. 2005. The depth distribution of soil organic carbon in relation to land use and management and the potential of carbon sequestration in subsoil horizons. Advances in Agronomy 88:35-66.

McCulley, R. L., E. G. Jobbágy, W. T. Pockman, and R. B. Jackson. 2004. Nutrient uptake as a contributing explanation for deep rooting in arid and semi-arid ecosystems. Oecologia 141:620-628.

Melillo, J., J. Aber, A. Linkins, A. Ricca, B. Perriy, and K. J. Nadelhoffer. 1989 Carbon and nitrogen dynamics along the decay continuum: plant litter to soil organic matter. Plant and Soil 115:189-198.

Myster, R. W., AND M. P. Malahy. 2008. Is there a middle way between permanent plots and chronosequences? Canadian Journal of Forest Research 38:3133-3138.

Norby, R. J., AND R. B. Jackson. 2000. Root dynamics and global change: seeking an ecosystem perspective. New Phytologist 147:3-12.

Paustian, K., W. J. Parton, and J. Persson. 1992. Modeling soil organic matter in organic-amended and nitrogen-fertilized long-term plots. Soil Science Society of America Journal 56:476-488.
Pavón, N. P. 2005. Biomass and root production of two plant life forms in a semiarid Mexican scrub: responses to soil nitrogen availability. Canadian Journal of Botany 83:1317-1321.

Perry, J. N., A. M. Liebhold, M. S. Rosenberg, M. M. Dungan, A. Jakomulska, and S. Citron-Pousty. 2002. Illustrations and guidelines for selecting statistical methods for quantifying spatial pattern in ecological data. Ecography 25:578-600

Saetre, P., and J. M. Stark. 2005. Microbial dynamics and carbon and nitrogen cycling following re-wetting of soils beneath two semi-arid plant species. Oecologia 142:247-260.

SAS [Computer PRogram]. 2006. SAS learning edition 4.1 (4.1.99.492). Cary, NC, USA: SAS Institute, Inc.

SCHENK, H. J., AND R. B. JACKSON. 2002. The global biogeography of roots. Ecological Monographs 72:311-328.

Shaw, M. R., and J. HaRte. 2001. Control of litter decomposition in a subalpine meadow-sagebrush steppe ecotone under climate change. Ecological Applications 11:1206-1223.

Sherrod, L. A., G. Dunn, G. A. Peterson, and R. L. Kolberg. 2002. Inorganic carbon analysis by modified pressure-calcimeter method. Soil Science Society of America Journal 66:299-305.

SILVA, J. S., AND F. C. REgo. 2003. Root distribution of a Mediterranean shrubland in Portugal. Plant and Soil 255:529-540.

Smith, J. L., J. J. Halvorson, and H. Bolton. 2002. Soil properties and microbial activity across a $500 \mathrm{~m}$ elevation gradient in a semi-arid environment. Soil Biology and Biochemistry 34:1749-1757.

StURGES, D. L. 1977. Soil water withdrawal and root characteristics of big sagebrush. American Midland Naturalist 98:257-274.

Subke, J., I. IngLima, And F. Cotrufo. 2006. Trends and methodological impact in soil $\mathrm{CO}_{2}$ efflux partitioning: a metaanalytical review. Global Change Biology 12:921-943.

Systat [Computer program]. 2004. SigmaPlot 9.01. Chicago, IL, USA: Systat Software, Inc.

Thornley, J. H. M., And M. G. R. Cannell. 1997. Temperate grassland responses to climate change: an analysis using the hurley pasture model. Annals of Botany 80:205-221.

us Department of Agriculture, Natural Resources Conservation Service. 2007. The PLANTS database. Available at: http://plants.usda.gov. Accessed 3 December 2006.

Vargas, R., M. F. Allen, and E. B. Allen. 2008. Biomass and carbon accumulation in a fire chronosequence of a seasonally dry tropical forest. Global Change Biology 14:109-124.

Wambolt, C. L., K. S. Walhof, and M. R. Frisina. 2001. Recovery of big sagebrush communities after burning in south-western Montana. Journal of Environmental Management 61:243-252

WeSt, N. E. 1983. Temperate deserts and semi-deserts. Volume 5. Ecosystems of the world. Amsterdam, Netherlands: Elsevier. 522 p.

Western Regional Climate Center. 2007. Saratoga 1 sse, wyoming. Available at: http://www.wrcc.dri.edu/cgi-bin/cliMAIN.pl?wy7990. Accessed 25 February 2007.

Yanal, R. D., W. S. CurRiE, And C. L. Goodale. 2003. Soil carbon dynamics following forest harvest: an ecosystem paradigm reviewed. Ecosystems 6:197-212.

Yin, X. W., J. A. Perry, and R. K. Dixon. 1989. Fine-root dynamics and biomass distribution in a Quercus ecosystem following harvesting. Forest Ecology and Management 27:159-177. 